\title{
The Application of Genre-Based Teaching Approach in College English Reading Teaching
}

\author{
Li Meijing \\ Foreign Language Department \\ Jilin Business and Technology College \\ Changchun, China \\ 182076127@qq.com
}

\begin{abstract}
Genre-based teaching approach has exerted a profound influence on English teaching in the second language environment and also causes the extensive concern of foreign language teaching in our country, but it is still in the stage of theoretical exploration. The true sense of the classroom teaching practice is still relatively rare. This paper, on the basis of theoretical analysis, combined with the current situation of college English reading teaching and personal teaching experience, proposes the classroom teaching steps of genre-based teaching approach and some problems what should be paid attention to.
\end{abstract}

Keywords-college English; reading teaching; genre-based teaching approach

\section{INTRODUCTION}

College English Teaching Syllabus makes a request for college English teaching in two levels, cultivating students to be provided with strong reading ability and certain listening, speaking, writing and translating ability. Obviously, the cultivation of reading ability is in the first place. The College English Teaching Syllabus further stresses that college English teaching should always pay attention to the cultivation of reading ability. The requirement conforms to the law of language learning and adapts to the actual situation in our country. First of all, reading is the foundation of improving students' comprehensive ability of using language, because the improvement of English application ability is based on a lot of language input, especially on the basis of extensive reading ${ }^{[1]}$. Moreover, the actual situation in our country over the past 20 years, despite the rapid development of college English teaching, is still far from students' proficiency at listening, speaking, reading, writing and translating. Reading is still the main foreign language skill that most people need in the future. Therefore, how to improve the current college English reading teaching and effectively improve the students' reading ability is the common goal and top priority which college English teachers should make great efforts to achieve.

\section{THEORETICAL FRAMEWORK}

\section{A. Genre}

With the development of discourse analysis, linguists are no longer satisfied with the analysis of the language itself. They have developed a strong interest in social and cultural factors of genre analysis. Martin (1987) argued that genre is behavior with clear step and target. Miller (1984) argued that genre is not only a type of discourse but also a kind of social behavior. Swales (1990) argued that genre is a kind of social event. Singapore Bhatia (1993), on the basis of Swales' genre theory, made further perfection. He thought: 1) Genre is a recognizable social events; 2) Genre is not a general social event, but a highly conventionalized social event with clear internal structure and characteristic; 3) In the construction of discourse, it must follow a practice required by a particular genre; 4) Despite the convention and conditionality of genre, starters can still convey personal intention and communication purposes within the genre regulations. (Qin Xiubai, 2002:99). On the understanding of the genre, linguists have their own views. But they all agreed that the communicative purpose determines the genre and the different communicative purposes determine the pattern of the discourse structure, which to a large extent affects the choice of content and style.

\section{B. Genre Analysis}

Genre analysis is a research on the use of the language in a specific context. The genre of Different discourse is different because of their different communicative purpose. In order to achieve their communicative purposes, their language and structure will change accordingly. For nearly 30 years, the analysis of context has gradually changed from stylistic analysis and register analysis to the trend of genre analysis. Namely the analysis of discourse is changing gradually from the surface to the depth. Genre analysis not only applies the linguistic method, but also combines sociology and psychology together to analyze discourse. Linguistic method is mainly used for the description of linguistic features of the discourse. Sociological method reveals the social and cultural factors that a specific genre structure can form and develop. Psychological method reveals the cognitive structure and the construction strategy related to a certain genre in special field and discusses how a specific communicative purpose shall be implemented in a specific discourse ${ }^{[2]}$.

\section{Genre-based Teaching Approach}

Genre approach is based on genre analysis and applies genre analysis theory in the classroom teaching which is a method to carry out teaching activities surrounding the schemata structure of discourse. The aim of genre approach is to let the students understand different genres of discourse with 
different communicative purposes and discourse structures, help students realize the discourse construction is not only a kind of linguistic construct but also a kind of social meaningful construct and enables students not only to master the discourse schema structure but also to understand the construction process of discourse, so as to help students understand and create a discourse belonging to a particular genre (Kay \& Dudley Evans, 1998). Since the 1980s, more and more linguists show a keen interest in genre approach. In the application of genre approach, three schools have sprung up ${ }^{[3]}$ :

- 1) Genre teaching method in the field of ESP and EAP. Experts in the field believe that the implementation of the genre approach can help learners whose mother tongue is not English master the discourse functions and language convention in the respective field of language;

- 2) New rhetoric school researchers emphasize the social context of genre. They do not focus on the analysis of the textual structure, but pay more attention to helping college students and people engaged in a certain field understand the social function, application occasion and context of genre (Freedman \& Med way, 1994);

- 3) The researchers of Australian school argue that genre is a step-by-step and purposeful language event. Therefore, the discourse under a genre must have a pattern in its structure. Genre-based teaching method of Australian school aims to help students be proficient in reading and writing academic and professional discourse. In order to adapt to the need of social development and international exchange in our country, has become an urgent task to cultivate students' effective communicative ability. Genre-based teaching approach views reading as a form of communication and focuses on the analysis of discourse, which believes that any professional article has its inherent structure and characteristic, so, teachers should help students sum up the content and structural schemata through reading model essays.

Thus, when students meet a variety of genres in reading, they have owned a clear schema structure. According to cognitive theory, if the students are familiar with the discourse structure and content of a particular genre, the cognitive schemata in their memories will be activated and their reading ability and speed will get greatly improved accordingly. Genre analysis of reading essays aims to provide students with a relatively stable cognitive schemata and a reference for them in future reading. This helps to improve students' self-confidence and reading interest, and thus improve their reading ability and communication skills.

\section{The Application Of GENRE-BASEd TEACHING APPROACH IN COLLEGE ENGLISH CLASSROOM}

Genre-based teaching approach is a teaching method using genre analysis theory in classroom teaching. Sunny Hyon from University of Michigan, under the guidance of John M. Swales, conducted a genre-based reading teaching experiment and achieved considerable results. The main teaching steps include genre analysis, imitation analysis, group discussion, independent study thorough analysis and imitation writing ${ }^{[3]}$.

Genre-based teaching approach has welcomed by a majority of teachers and students and received high praise since its foundation. Many English teachers believe that genre-based teaching approach is an effective way of teaching. In recent years, as more and more English teachers physically apply this method to reading teaching practice, domestic scholars start to conduct deeply research on the approach. Engaged in English teaching for many years, the writer has tried a variety of teaching methods ${ }^{[4]}$. Compared with the traditional teaching methods in the past, genre-based teaching approach has many advantages. It views reading activities as a process of social communication and pays attention to the discourse pattern analysis of reading essays due to the fixed structure and characteristic of literature in any field. Teachers can help students come to the conclusion that can follow the rule and draw lessons from mode of discourse so as to create a shortcut for students and make them to enhance the confidence and interest in English learning. Students, after mastering the discourse pattern, can draw inferences about other cases from one instance and create more forms of discourse, thus, their creative thinking ability can be trained as a matter of course. In addition, the teaching method has changed the traditional role of teachers.

Teachers are no longer the dictators of traditional classroom, but the organizers, coordinators and answerers in the classroom teaching. Students' roles also change from passive receivers to active explorers, thus their enthusiasm in English learning can be greatly improved. Genre-based teaching approach, however, inevitably has some deficiencies. For Chinese students who learn English as a second language, genre-based teaching approach in particular walks with difficulty in classroom teaching. First of all, in the context of the current situation of college English teaching in China, it's hard to carry on smallclass teaching, which makes some teaching steps, such as independent analysis and team analysis, fail to achieve a desired effect. Secondly, differences between eastern and western countries in the way of thinking and cultural background make students' understanding of discourse pattern and language style appear unavoidable error, which further hinders their accurate control of genre.

Moreover, genre-based teaching approach has strong conventional colors. If teachers can't control this characteristic in classroom teaching, it is probably easy to tie the students' imagination and creativity. Based on the above analysis, we believe that genre-based teaching approach also has the inherent shortcomings despite it has obvious advantages compared with any kind of traditional teaching method. Only genre-based teaching approach is combined closely with the concrete practice of traditional English teaching in our country is it able to foster strengths and circumvent weaknesses and improve students' reading level in a short period. The writer has experience in English teaching for many years and divides the teaching process of genre-based teaching approach into the following four stages according to his own experience and exploration: 
- The first stage: genre analysis. Referring to Bhatia's theory of genre analysis, teachers make a detailed analysis of the selected reading essays, including two aspects of culture and language. In genre approach, genre is seen as a kind of social behavior and essay as part of social situation because social situation is crucial to the formation of the essay's pattern. The characteristics of these scenarios and purposes of the participants have high conditionality and stipulation to reading essays. Therefore, teachers must introduce society, history, customs and habits related to genres comprehensively for students. In terms of language, teachers should not only analyze the vocabulary and grammatical features of the essays but also analyze the textual features of the essays. More importantly, teachers must enable students to grasp the structural characteristics of the essays because the essence of the genre approach is starting from the special structure of different genres to let students understand the application features of such essays. Analysis of the structural characteristics, as it were, is the top priority of teaching process.

- The second stage: group discussion. Students are divided into several groups to discuss the following issues: if there is a difference in the use of this genre between east and west and what is the difference; how to promote communicative purpose of special structure of this genre; are the participants of the genre in common. Group discussion is in order to achieve the purpose of students' full participation and promote and help the students understand. As to the form of group discussion, teachers may according to the class size and students' English level choose questioning techniques, involvement techniques, feedback techniques, review techniques and pupil supportive techniques (Antonellis, 1983: 23-26).

- The third stage: independent analysis. Teachers are supposed to choose a piece of typical model essay related to this genre for students and let students imitate the method used by teachers in the first phase from the perspectives of both cultural and linguistic analysis. One of the advantages of genre approach is that it has changed the role of the teachers in traditional classroom, provides students with the opportunity of independent thinking in classroom teaching and enables students to grasp, digest and apply the knowledge. At this stage, teachers must abandon the authority role to be the "giver of knowledge" and become an active and collaborative "facilitator" or "helper".

- The fourth stage:: strengthening practice. The teaching process is different from the above three ones because it is an essential part of traditional teaching. To play the advantages of genre-based teaching method thoroughly, teachers must reform the process. The way of practice long used has exerted a great influence on teachers and is inevitably restricting the implementation of the genre-based teaching approach. Therefore, the author will make a more detailed analysis of the teaching process in order to attract the attention of everybody.

At present, most of the students' reading comprehension exercises adopt multiple choice, open questions, true/false judgement and topic sentences identification, etc., but according to George S. Murdoch's analysis (1986 Murdoch: 912), they are all flawed. Multiple choice questions can't effectively help the students understand the text. Open questions inevitably cause students to copy original sentences. True/false judgement only can test students' understanding of the text. If students can't completely understand the topic sentence's message and fail to connect the topic sentence's message to the strategy and structure of the whole essay, topic sentences identification is of no value.

Successful language learners should be able to fully understand the original text, extract the needed information with integration of the acquired knowledge and convey obtained knowledge to others. In view that the above forms of practice cannot effectively improve the comprehensive ability of students, Murdoch designed more open-ended ways of practice for English teachers. He divided these exercises into two categories: exercises focused on the text and exercises extending from the text. Exercises focused on the text include the following eight forms:

TABLE I. Exercises focused on the text ${ }^{[5]}$

\begin{tabular}{|c|c|}
\hline 1. Priming questions & $\begin{array}{l}\text { Prepare sentences or questions concerning the theme } \\
\text { and background of essays for students and let the } \\
\text { students establish correct psychological preparation } \\
\text { for the upcoming reading. }\end{array}$ \\
\hline $\begin{array}{l}\text { 2. Detective } \\
\text { questions }\end{array}$ & $\begin{array}{l}\text { Let students find specific information in the essay, } \\
\text { which can exercise their ability to quickly find the } \\
\text { required information and improve their reading } \\
\text { speed. }\end{array}$ \\
\hline $\begin{array}{l}\text { 3. Margin } \\
\text { "knowledge" } \\
\text { questions }\end{array}$ & $\begin{array}{l}\text { These questions are timely raised by teachers in the } \\
\text { process of classroom reading and the students write } \\
\text { the answers in the blank space in the relevant part of } \\
\text { the article, which mainly aims to stimulate the } \\
\text { students associate the related knowledge learnt in the } \\
\text { past. }\end{array}$ \\
\hline $\begin{array}{l}\text { 4. Cohesion } \\
\text { questions }\end{array}$ & $\begin{array}{l}\text { These questions are mainly for syntactic and } \\
\text { semantic practice, such as to reference, repetition, } \\
\text { synonymy and omission. Understanding them is the } \\
\text { foundation to understand the thoughts of the author. }\end{array}$ \\
\hline $\begin{array}{l}\text { 5. Understanding the } \\
\text { text }\end{array}$ & $\begin{array}{l}\text { Test students' understanding of the text in the form } \\
\text { of complementing sentences. Exercise design should } \\
\text { avoid students directly using the words and sentences } \\
\text { in the essay. }\end{array}$ \\
\hline $\begin{array}{l}\text { 6. Information } \\
\text { transfer }\end{array}$ & $\begin{array}{l}\text { Let students play the information provided by the } \\
\text { essay in the other form, such as tables, graphs, plans, } \\
\text { etc. }\end{array}$ \\
\hline 7. Summaries & $\begin{array}{l}\text { Ask students to list the main points of the essay and } \\
\text { learn how the author offers a concise and } \\
\text { comprehensive view. }\end{array}$ \\
\hline $\begin{array}{l}\text { 8. Dictionary } \\
\text { exercise }\end{array}$ & $\begin{array}{l}\text { Although teachers expect students to guess the } \\
\text { meaning of the unknown words as far as possible, } \\
\text { they could not guess all the meanings of new words. } \\
\text { Besides, referring to dictionary can also make them } \\
\text { fully understand a word. }\end{array}$ \\
\hline
\end{tabular}
forms.

Exercises extending from the text include the following six 
TABLE II. Exercises extending from the text

\begin{tabular}{|c|l|}
\hline 1. Paragraph structure & $\begin{array}{l}\text { Ask students to complete the } \\
\text { paragraph structure flow chart. }\end{array}$ \\
\hline 2. Prediction exercise & $\begin{array}{l}\text { Let students predict the author's } \\
\text { writing thoughts or another possible } \\
\text { ending. }\end{array}$ \\
\hline 3. Jigsaw exercise & $\begin{array}{l}\text { Divide the essay into several parts, } \\
\text { disorder all the parts and let students } \\
\text { recombine together. }\end{array}$ \\
\hline 4. The function of sentences & $\begin{array}{l}\text { Understand the relationship between } \\
\text { two sentences up and down through } \\
\text { adverbs like "for example" and } \\
\text { "however". }\end{array}$ \\
\hline 5. Grammar review & $\begin{array}{l}\text { Review and consolidate grammatical } \\
\text { points in the context. }\end{array}$ \\
\hline 6. Vocabulary follow-up & $\begin{array}{l}\text { Pick out the new words in the essay, } \\
\text { delete one or more letters and let } \\
\text { students supplement out or make } \\
\text { new words. }\end{array}$ \\
\hline
\end{tabular}

\section{CONCLUSION}

In the concrete teaching practice, it is the key to the success of teaching which method teachers adopt. Despite the genrebased teaching approach is still in the exploratory stage, ten years' practice has proved that it is an effective way to improve college English reading teaching and students' reading level.
At the same time, genre-based teaching approach puts forward higher requirements for English teachers. It not only requires teachers to have strong professional knowledge and teaching method, but also requires teachers to have certain research on linguistics, psychology, sociology and other related fields. English teachers are supposed to constantly enrich themselves and expand their horizons to make the genre-based teaching approach applicable in the teaching reform and cultivate more qualified foreign language talents for our country.

\section{REFERENCES}

[1] Antonellis M K . Some Techniques for Group Instruction [J] .English Teaching Forum, 1983:23-26

[2] Qin Xiubai. Review of genre analysis[J] . Foreign Language Teaching and Research, 2000 , (1) : 42-46

[3] Martin J R. English Text: system and structure[M] . Amsterdam: Benjamins, 1992.

[4] Nunan D . Language Teaching Methodology [M] .Hemel Hempstead: Prentice Hall , 1991.

[5] Higher education department of the People's Republic of China. College English Curriculum Requirements[Z] . Foreign Language Teaching and Researc, 2004 